\title{
La factura en el entorno comercial iberoamericano. Especial referencia a Cuba ${ }^{1}$
}

\section{The invoice in the iberoamerican commercial context. Special reference to Cuba}

\author{
YOANDIS SÁNCHEZ SUÁREZ²
}

\section{RESUMEN}

Las relaciones propias de la actividad comercial tienen su expresión en la factura, documento privado que si bien dinamiza el mercado, requiere de adaptarse a la mutabilidad inherente a ese contexto. En consecuencia, el presente artículo se centra en las particularidades teóricas y normativas de la factura en países iberoamericanos representativos, su interacción con el crédito y la cesión de este, acudiéndose a la sistematización e integración de criterios doctrinales significativos, complementada con un examen exegético y comparado de la legislación aplicable, para luego abordar su manifestación en el ámbito cubano.

Palabras clave: Factura ${ }_{i}$ comercio $;$ crédito

1 Fecha de recepción: 2 de octubre de 2018. Fecha de aceptación: 5 de diciembre de 2018. Para citar el artículo: Sánchez Y. "La factura en el entorno comercial iberoamericano. Especial referencia a Cuba". En Revist@ E-Mercatoria, vol. 17,n. ${ }^{\circ}$ 2. julio-diciembre 2018. DOI: https://doi. org/10.18601/16923960.v17n2.02

2 Licenciado en Derecho (Academia Militar Arides Estévez, La Habana, 2000); Diplomado en Derecho de Empresa (Universidad de Granma, 2007), Diplomado en Derecho Laboral (Universidad de Oriente, 2008); Máster en Ciencias Jurídicas (Universidad de Oriente, 2015); ha publicado artículos en revistas iberoamericanas sobre temas mercantiles y laborales desde 2007; en formación doctoral en Ciencias Jurídicas (Universidad de La Habana); asesor jurídico de empresas cubanas entre 2000 y 2015, alternando desde 2003 la práctica profesional con el ejercicio de la docencia universitaria; actualmente es Profesor Auxiliar de Derecho Mercantil de la Universidad de Granma; nacional cubano; correo de contacto: ysanchezs@udg.co.cu 


\begin{abstract}
The relations of the commercial activity have its expression in the invoice, a private document that, while dynamising the market, requires adapting to the mutability inherent in that context. Consequently, this article focuses on the theoretical and normative particularities of the invoice in representative iberoamerican countries, its interaction with credit and its assignment, resorting to the systematization and integration of significant doctrinal opinions, complemented with an exegetical and comparative examination of the applicable law, to then approach its manifestation in the cuban context.
\end{abstract}

Keywords: Invoice; commerce ; credit

\title{
SUMARIO
}

Introducción. I. Caracterización preliminar de la factura. II. Modalidades que presenta la factura. A. Factura en papel. B. Factura electrónica. C. Factura cambiaria. III. Utilidad de la factura, a tres dimensiones. IV. La factura desde el contexto cubano.

\section{INTRODUCCIÓN}

Señala Naciones Unidas que los efectos de la crisis financiera mundial de 2008 han amainado, aunque el crédito creció con fuerza, de manera que las perspectivas estarán sujetas a tres factores puntuales: cambios en las políticas comerciales, deterioro repentino de las condiciones financieras del orbe y las crecientes tensiones geopolíticas, como también urge coordinar las políticas monetarias, fiscales y cambiarias para alcanzar estabilidad. ${ }^{3}$

Dentro de ese escenario global tiene lugar la actividad comercial; se compite en el mercado en tanto espacio y mecanismo propicio para expandir los negocios, que coadyuva a la realización misma del ciclo productivo, comercial o de servicio, para alcanzar el ánimo de lucro. Tal interacción descansa sobremanera en el contrato, de modo que las relaciones presentan una consecuencia financiera, expresada en obligaciones pecuniarias, en las que acreedor y deudor tiran de sus intereses.

En efecto, la acción misma cobro-pago de adeudos condiciona el consiguiente aumento de las transacciones, precedidas necesariamente de la emisión de documentos, entre los que sobresale la factura, tenida a priori como el soporte

3 Vid. Naciones Unidas, "Situación y perspectivas de la economía mundial 2018", https:// www.un.org/development/desa/dpad/wp-content/.../WESP2018essp.pdf [consultado el 8 de febrero de 2018] 
principal del crédito, además de instrumento dinamizador del mercado, en tanto urgido de acomodarse a su mutabilidad.

Así se advierten diferencias sustanciales en la construcción teórica alrededor de la factura en el área iberoamericana, sobresaliendo España, Colombia, Chile, Perú, Ecuador y Venezuela entre el conjunto de naciones, igual destacadas por su consecuente reflejo de orden normativo, que unido a una mirada de este documento comercial a la luz del proceso de actualización del modelo económico cubano, resultaron las razones que inclinaron al autor a acometer el presente estudio.

\section{CARACTERIZACIÓN PRELIMINAR DE LA FACTURA}

Ubicada en la economía la génesis de la factura, sin embargo traspasó por sí misma el umbral jurídico. En criterio de Piloñeta, es el "documento privado emitido por un empresario o profesional en el ejercicio de su actividad, para dejar constancia de una determinada transacción y sirve de soporte al cumplimiento de sus obligaciones contables y fiscales". ${ }^{4}$

Para Prado resulta en la "consecuencia de relaciones contractuales de compraventa o de prestación de servicios u otras, que la ley asimila a aquellas y en muchas ocasiones, es el único documento que refleja estos actos y las obligaciones pendientes de pago, todo lo cual tiene un evidente valor tributario, comercial y contractual" ${ }^{15}$ y Carbajo la considera un documento mercantil que es medio de prueba de dos situaciones jurídicas: por un lado, la realización de operaciones de índole mercantil, y por otro, su deducibilidad a los efectos tributarios. ${ }^{6}$

Sostiene Delgado su breve visión de la factura "como documento en el que se plasma el objeto de un contrato", sobre todo en normativas mercantiles y fiscales. ${ }^{7}$ Más explícitos resultan Asencio y Guerra, quienes la advierten a través de la expedición por la empresa de "un documento demostrando que los bienes o servicios han sido vendidos $\mathrm{y}$, por lo tanto, el comprador deberá pagar un valor monetario por ello", sumado que la factura se emite por el vendedor, "es uno de los documentos más básicos utilizados en el comercio, generalmente expone la naturaleza de la mercancía vendida, el precio de venta, el tamaño de la unidad y costo total. ${ }^{8}$

4 Vid. Luis Manuel Piloñeta Alonso, Curso de Derecho Mercantil de la contratación (Oviedo: Editorial Ediuno, 2a ed., 2014), 55.

5 Vid. Arturo Prado Puga, "Alcance jurídico de la factura como título de circulación mercantil", Revista de Derecho, Pontificia Universidad Católica de Valparaiso, 46 (2016): 157.

6 Vid. DOMINGO CARBAJO VASCO, "Hacia una reforma de la normativa europea sobre facturación en el IVA", 2010, http://www.elderecho.com/tribuna/administrativo/reforma-normativaeuropea-facturacion-IVA_11_199555002.html, [consultado el 3 de enero de 2018]

7 Vid. ANA María Delgado GaRCía, "La regulación de la factura electrónica en el sector público", Revista de Internet, Derecho y Política, Universidad de Cataluña, 18 (2014): 98.

8 Vid. Angie Asencio Sandoval y Víctor Guerra Fuentes, Procedimientos de control interno 
Aunque en los postulados precedentes existen breves referencias al contenido de la factura, se tiene por necesario precisar a seguidas. Han de consignarse e individualizarse en la factura las mercaderías vendidas o arrendadas o la constancia de servicios prestados, agregando en todos los casos sus valores unitario y neto, el impuesto al valor agregado (IVA) -si se tratase de una operación gravada-, valor bruto a pagar, con precisión o no de fecha de pago, y su vigencia. ${ }^{9}$

O que una factura general normalmente se emite durante la entrega de la mercancía y requiere de información sobre su fecha ${ }_{i}$ el número de serie; identificación de sus organizadores -nombre comercial, oficina de impuestos y el número de cuenta-y del cliente -nombre comercial, dirección y número de cuenta sobre algún impuesto-; naturaleza del producto o negocio, cantidad y precio; número de guía $;$ y fecha de las mercancías vendidas. ${ }^{10}$

Un tercer enfoque, más bien oscilante, sustenta que el contenido de la factura varía según la transacción y prestaciones recíprocas que condujeron a su expedición:

En la práctica, las facturas indican la fecha en que son emitidas, las partes intervinientes en la operación, una referencia más o menos detallada de las cosas o servicios objeto de la misma y el precio en dinero de la transacción a satisfacer por el deudor. En ocasiones, se extiende sobre la factura un recibí o declaración de conformidad por alguna de las partes en torno a ciertos hechos, relacionados con la ejecución de la operación, como el pago del precio, la recepción de la mercancía o la prestación del servicio; de modo que su contenido se extiende también a tales circunstancias. ${ }^{11}$

Normativamente la tendencia es omitir la definición de la factura en los códigos comerciales; y en su defecto, el legislador la vinculó indirectamente con el contrato de compraventa ${ }^{12}$, o delineó su contenido. ${ }^{13}$

sobre la facturación para la Empresa FILIBÓN S.A. (tesis de pregrado, Universidad de Guayaquil, Ecuador, 2016), 8.

9 Vid. Arturo Prado Puga, op. cit., 166.

10 Vid. Angie Asencio Sandoval y Víctor Guerra Fuentes, op. cit., 9 y 10.

11 Vid. Rafael Lara González, "La factura en el Derecho Mercantil proyectado", en Estudios sobre el futuro Código Mercantil. Libro bomenaje al profesor Rafael Illescas Ortiz, ed. MARÍA JOSÉ MORILLAS (Madrid: Universidad Carlos III de Madrid, 2015), 2035.

12 Cfr. Código de Comercio de Nicaragua, Gaceta n. ${ }^{\circ}$ 248, de 30 de octubre de 1916, artículo 362, Ley n. ${ }^{\circ}$, Por la cual se aprueban los Códigos Penal, de Comercio, de Minas, Fiscal, Civil y Judicial, elaborados por la Comisión Codificadora, Gaceta Oficial n. ${ }^{\circ} 02404 \mathrm{~Pa}$ namá, de 22 de agosto de 1916, artículo 776; Código de Comercio de Venezuela, Gaceta n. ${ }^{\circ} 475$ Extraordinaria, de 21 de diciembre de 1955, artículo 147; y Código de Comercio de Ecuador, Registro Oficial n. ${ }^{\circ}$ 1202, de 20 de agosto de 1960, artículo 201.

13 En Argentina, su Código Civil y Comercial prescribe en el art.1145 que la factura contiene la descripción de la cosa vendida, precio o parte de este que ha sido pagada y los demás 
Así sobresale el carácter de documento privado que posee la factura, por reflejar la intervención mayoritaria de empresarios en el mercado, sumadas las particularidades de las relaciones contractuales que encierra. Igual muestra las prestaciones recíprocas de las partes, que resultan en transacciones ulteriores, incluidas las de tipo pecuniario, como presupuesto del par crédito-débito y, consecuentemente, legitima el momento de la adquisición de sus correlativos status, acreedor-deudor. Destaca además su emisión por el vendedor o prestador, para dejar constancia en el documento comercial sobre la concreción del negocio con el comprador o cliente y sus efectos.

Ante la inexistencia de una posición predominante sobre el contenido de la factura, el autor del presente artículo asume que al menos constarán datos esenciales, consistentes en las fechas de expedición y entrega, número o código, identificación de las partes, descripción del producto o servicio objeto del acto, incluidas su cantidad y precio, y su aceptación por el comprador o cliente a través de la firma que acostumbra a usar.

Si bien es limitado el empleo del término servicios dentro de los actos contractuales a reflejar en la factura, debe entenderse extensible a un grupo de figuras bajo tal naturaleza jurídica: comisión, agencia, mediación o corretaje, concesión, depósito, préstamo, fletamento, transporte terrestre y aéreo, seguro, servicios de intermediación financiera, entre otros $;$ a modo de la necesaria diferenciación con la compraventa.

La mutabilidad inherente a la actividad comercial propicia el surgimiento de modalidades de la factura, sin perder sus atributos, como se tratará a continuación.

\section{MODALIDADES QUE PRESENTA LA FACTURA}

\section{A. FACTURA EN PAPEL}

Aunque ya ofrecidas sus particularidades básicas, existe a partir del documento en soporte físico, corpóreo o tangible. La doctrina señala su forma tradicio-

términos de la venta ${ }_{i}$ mientras que el Código de Comercio boliviano y el Real Decreto n. ${ }^{\circ}$ 1619 español disponen en sus respectivos artículos 832 y 6, con cierta coincidencia, que en el contenido de la factura están su fecha de expedición, el número o serie, los datos del vendedor y el comprador, las características de las mercancías u operaciones (cantidad, calidad, tamaño, peso y valor), las condiciones de pago y la firma de los sujetos intervinientes, lo distintivo está, para Bolivia, en reflejar el número y demás detalles de la carta de porte y los contratos de fletamento y seguro, si los hubiera, y en España, desde el ámbito tributario, los datos para determinar la base imponible, el tipo impositivo y la cuota tributaria, o si la factura está exenta de impuesto. Cfr. Ley n. ${ }^{\circ}$ 26.994, Código Civil y Comercial de la Nación Argentina, Boletín Oficial de 8 de octubre de 2014; Decreto-Ley n. ${ }^{\circ} 14379$, Código de Comercio de Bolivia, Gaceta Oficial n. ${ }^{\circ}$ 907, de 1 de marzo de 1977; y Real Decreto n. ${ }^{\circ} 1619$, Por el que se aprueba el Reglamento por el que se regulan las obligaciones de facturación, Boletín Oficial del Estado n. ${ }^{\circ} 289$ España, de 1 de diciembre de 2012. 
nal en papel, que con el decursar del tiempo sumó otros calificativos ${ }^{14}$, hasta converger en la actual factura comercial, denominación atinada a su objeto: los actos de comercio diversos ejecutados entre empresarios o surgidos de sus relaciones con otros sujetos, en ocasión de intervenir en el mercado.

\section{B. FACTURA ELECTRÓNICA}

No puede soslayarse la incidencia de las tecnologías de la información y las comunicaciones ${ }^{15}$ sobre el comercio, llevando a la sustitución paulatina del documento en papel por su similar virtual ${ }^{16}$, de ahí que aparece la factura electrónica. Sus diferencias con la factura en papel se acentúan en la manera impersonal en que intervienen las partes, el uso de los medios automatizados para conformarla y la transmisión de datos.

Más que definir la factura electrónica, es posible hablar de aspectos característicos, como considerársele la versión digital de la factura en papel, accediendo a su contenido on line o en línea, acompañada de la firma electrónica, cual respaldo de la transacción realizada, e igual de válida que una firma escrita, siempre observados sus requisitos legales. ${ }^{17}$

14 Sánchez Calero la nombra factura tradicional e indistintamente Lara la cataloga de factura en papel y factura ordinaria, con un mismo significado. Delgado también recurre a la factura ordinaria, y Asencio y Guerra aluden al llenado de forma manual mecánica, resultando la factura papel o factura impresa. Vid. FERNANDO SÁNCHEZ CALERO, Instituciones de Derecho Mercantil (Madrid: Editoriales de Derecho Reunidas, $\left.17^{\mathrm{a}} \mathrm{ed} ., 1994\right), 6$; RAFAEL LARA GONZÁlEZ, op. cit., 2036 y 2038; ANA MARía DELGado GarCía, op. cit., 99; y ANGIE ASENCIO SANDOVAl y Víctor GUERRA FuENTES, op. cit., 8.

15 Precisan Álvarez y Correa que el comercio electrónico o e-commerce es la compra y venta de productos y servicios por medios electrónicos. "La tendencia de los teléfonos móviles inteligentes, ordenadores, tabletas y un sinnúmero de elementos tecnológicos, como aplicaciones, páginas web y redes sociales, han cambiado la oferta del mercado, actualmente una persona hace sus compras más personalizadas (...), el medio electrónico permite acceder a cualquier tienda virtual independientemente de donde esté ubicado su administrador electrónico". Zubillaga acude a la economía digital, cuyo activo es la información, con las tecnologías digitales como el elemento clave para el desarrollo del negocio de nuevos productos y servicios, o mediante nuevos mercados digitales. Vid. DANIELA ÁlvarEZ MONTOYA y EliANA CRISTINA CORREA PATIÑO, "El impacto del e-commerce en la cadena logística de las empresas importadoras de la ciudad de Medellín", Revista En-Contexto, Instituto Tecnológico de Antioquia, 6:8 (2018): 86 y 87; y Agustín Zubillaga ReGO, "Informe de economía y sociedad digitales en el País Vasco", 2018, http://www.orkestra.deusto.es/euskadigitala/ data/economia-sociedad-digitales-pais-vasco.pdf [consultado el 8 de febrero de 2018].

16 Considera Jurado que bajo el principio de equivalencia funcional, el documento electrónico se equipara, o surte los mismos efectos, que el documento en soporte papel, o sea, que cumplen igual función en todo acto jurídico su instrumentación en soporte papel, con su firma autógrafa, o de manera electrónica, a través de un mensaje de datos. Vid. AlBERTO JURADO, "Valor probatorio del documento electrónico", Revista Cuestiones Jurídicas, 5:1 (2011): 56 y 57.

17 Vid. JESSICA GEOVANNA RODRÍGUEZ CHICAIZA, La facturación electrónica vs control fiscal. Análisis comparado con las administraciones tributarias de Chile y España (tesis de maestría, Universidad Andina Simón Bolívar, Ecuador, 2015), 30 y 31. 
Generalmente no existe un formato estricto de la factura electrónica, siendo recomendable se soporte en un fichero estándar con extensiones $x m l$, $p d f, b t m l, d o c, x l s$, jpeg o $t x t$, que compatible con el software del destinatario, le facilite abrirlo, verificar la identidad del emisor y la integridad de la factura, luego de validar la firma electrónica, para la que se sugieren las extensiones pkcs7, XadES y pdf ${ }^{18}$, incluso se tiene como documento original, sin que pueda sustituir a la factura en papel, equiparse a ella o considerarse un duplicado. ${ }^{19}$ Cual sistema, la factura electrónica requiere del mensaje de datos y la firma electrónica, según se corporifica en países que resaltan en el área iberoamericana (Ecuador, Venezuela, Panamá, Chile y España) ${ }^{20}$, valorada desde la perspectiva jurídico-comparada.

Predomina la definición expresa ${ }^{21}$ de la factura electrónica, no obstante se reconoce tácitamente en territorio venezolano ${ }^{22}$, dada la seguridad jurídica

18 Vid. Juan Jesús Martos García, "La integridad del contenido y la autenticidad de origen en la transmisión o puesta a disposición de la factura", Revista de Internet, Derecho y Política, Universidad de Cataluña, 12(2011): 88 y 89.

19 Ana María Delgado García, op. cit., 99.

20 Cfr. Ley n. ${ }^{\circ} 67$, Ley de Comercio Electrónico, Firmas y Mensajes de Datos, Registro Oficial n. ${ }^{\circ} 557$ Ecuador, de 17 de abril de 2002; Decreto n. ${ }^{\circ} 1.204$, Decreto con Fuerza de Ley sobre Mensajes de Datos y Firmas Electrónicas, Gaceta Oficial n. ${ }^{\circ} 37.076$ Venezuela, de 13 de diciembre de 2000; Ley n. ${ }^{\circ} 51$, Que define y regula los documentos electrónicos y las firmas electrónicas y la prestación de servicios de almacenamiento tecnológico de documentos y de certificación de firmas electrónicas y adopta otras disposiciones para el desarrollo del comercio electrónico, Gaceta Oficial n. ${ }^{\circ} 26.090$ Panamá, de 24 de julio de 2008; Ley n. ${ }^{\circ}$ 19.983, Que regula la transferencia y otorga mérito ejecutivo a copia de la factura, Diario Oficial Chile, de 15 de diciembre de 2004; Decreto Supremo n. ${ }^{\circ} 93$, Reglamento para la aplicación del artículo noveno de la Ley n. ${ }^{\circ} 19.983$, respecto de la cesión de créditos contenidos en una factura electrónica, Diario Oficial Chile, de 13 de abril de 2005; Ley n. ${ }^{\circ} 56$, De Medidas de Impulso de la Sociedad de la Información, Boletín Oficial del Estado n. ${ }^{\circ} 312$ España, de 29 de diciembre de 2007; Real Decreto n. ${ }^{\circ} 1619$, cit. Ley n. ${ }^{\circ} 25$, De Impulso de la Factura Electrónica y Creación del Registro Contable de Facturas en el Sector Público, Boletín Oficial del Estado n. ${ }^{\circ} 311$ España, de 28 de diciembre de 2013; y Ley n. ${ }^{\circ}$ 59, De Firma Electrónica, Boletín Oficial del Estado n. ${ }^{\circ} 304$ España, de 20 de diciembre de 2003.

21 Cfr. Ley n. ${ }^{\circ} 67$, cit., disposición general novena, párrafo décimo noveno: "conjunto de registros lógicos archivados en soportes susceptibles de ser leídos por equipos electrónicos de procesamiento de datos que documentan la transferencia de bienes y servicios, cumpliendo los requisitos exigidos por las Leyes Tributarias, Mercantiles y más normas y reglamentos vigentes"; Ley n. ${ }^{\circ}$ 51, cit., art. 2, apartado 18: "documento electrónico mediante el cual se deja constancia de la realización de la venta de bienes o de la prestación de servicios por parte de un prestador de servicios comerciales por medios electrónicos y que, a la vez, permite dar validez tributaria a operaciones comerciales efectuadas"; Ley n. ${ }^{\circ} 56$, cit., art.1.1, segundo párrafo: "A estos efectos, se entenderá que la factura electrónica es un documento electrónico que cumple con los requisitos legal y reglamentariamente exigibles a las facturas y que, además, garantiza la autenticidad de su origen y la integridad de su contenido, lo que impide el repudio de la factura por su emisor"; y Real Decreto n. ${ }^{\circ} 1619$, cit., ordenando en el art. 9 que la factura electrónica se ajusta a ese Reglamento, su expedición y recepción en formato electrónico y estar condicionada al consentimiento del destinatario. 
de que deben estar dotadas las comunicaciones, transacciones, actos y demás negocios electrónicos; excepto Chile, que la iguala a su versión en papel y luego relaciona los documentos tenidos dentro de la forma electrónica. ${ }^{23}$

Como peculiaridad, España regula por separado su uso en los sectores privado y público. Por un lado, empresarios o profesionales están obligados a expedir facturas por las operaciones realizadas en su actividad ${ }^{24}$, y por otro, se franquea la posibilidad de emitir o no facturas electrónicas a los proveedores de bienes o servicios a la Administración Pública, lo que sí es obligatorio tratándose de sociedades mercantiles, otras personas jurídicas y entes sin personalidad jurídica. ${ }^{25}$

Respecto al mensaje de datos, las normativas venezolana y ecuatoriana presentan cierta coincidencia, que a grosso modo es la información creada, intercambiada y archivada por medios electrónicos ${ }^{26}$; a su vez, Panamá ofrece tutela a la información electrónica, siempre que permanezca completa e inalterada ${ }^{27}$, y en España se materializa en el sello electrónico. ${ }^{28}$

La firma electrónica se concibe en los países estudiados ${ }^{29}$ según estos elementos: conjunto de datos, consignados o asociados a documento electró-

22 Cfr. Decreto n. ${ }^{\circ} 1.204$, cit.

23 Cfr. Ley n. ${ }^{\circ} 19.983$, cit., art. 9; y Decreto Supremo n. ${ }^{\circ} 93$, cit., art. $1^{\circ}$ : "Para los efectos de este Reglamento se entenderá por (...) b) factura electrónica: facturas de venta, facturas de compra, facturas exentas y liquidaciones factura, generadas como un documento electrónico emitido y firmado por un contribuyente autorizado por el Servicio de Impuestos Internos".

24 Cfr. Real Decreto n. ${ }^{\circ} 1619$, cit., art.1.

25 Cfr. Ley n. ${ }^{\circ} 25$, cit., art. 4.1.

26 Cfr. Decreto n. ${ }^{\circ} 1.204$, cit., art. 2: "Toda información inteligible en formato electrónico o similar que pueda ser almacenada o intercambiada por cualquier medio"; y Ley n. ${ }^{\circ} 67$, cit., disposición general novena, párrafo primero: "es toda información creada, generada, procesada, enviada, recibida, comunicada o archivada por medios electrónicos, que puede ser intercambiada por cualquier medio. Serán considerados como mensajes de datos, sin que esta enumeración limite su definición, los siguientes documentos electrónicos, registros electrónicos, correo electrónico, servicios web, telegrama, télex, fax e intercambio electrónico de datos".

27 Cfr. Ley n. ${ }^{\circ}$ 51, cit., art. 5. Así mismo, su art. 4 reconoce el mensaje de datos como documento escrito.

28 Cfr. Ley n. ${ }^{\circ} 25$, cit., art. 5, párrafo final: "es el conjunto de datos en forma electrónica, consignados o asociados con facturas electrónicas, que pueden ser utilizados por personas jurídicas y entidades sin personalidad jurídica para garantizar el origen y la integridad de su contenido".

29 Cfr. Ley $n .{ }^{\circ} 67$, cit., art. 13, unido al art. 14, que le atribuye los mismos efectos jurídicos de la firma manuscrita; Decreto n. ${ }^{\circ} 1.204$, cit., art. 2, en relación al art. 16, atribuyendo similar validez que la firma autógrafa, con las opciones de enviarse o no la firma electrónica en un mismo acto o mensaje de datos; Ley n. ${ }^{\circ} 51$, cit., art. 2, apartado $20_{;}$y Ley n. ${ }^{\circ} 59$, cit., art. 3, apartado 1, en sus variantes avanzada y reconocida, apartados 2 y 3 respectivamente, permitiendo la primera identificar al firmante y el cambio ulterior de sus datos, solo vinculada a él, creada por medios y bajo su exclusivo control, y la segunda se basa en 
nico, información que identifica al titular, que reconoce el mensaje dirigido al destinatario, quien lo acepta o se adhiere a su contenido; salvo Chile, que particulariza en la intervención de emisor y receptor, aquel utilizando su firma electrónica y este acudiendo al acuse de recibo electrónico para confirmar que tiene en su poder, o les fueron prestados, según el caso, las mercaderías o servicios que consten en la factura. ${ }^{30}$

Se trae a colación la factura electrónica desde la ciencia de las telecomunicaciones, en particular la arquitectura de la plataforma de facturación y pago: creación de las cuentas de usuario; manejo y administración de las cuentas del servicio de facturación y pago; almacenamiento y administración de la información de los usuarios; interfaz con el banco; pago de los productos; envío de mensajes informativos al usuario; envío de la factura digital al usuario, certificación de los participantes en el proceso $;$ y firma digital de la factura. ${ }^{31}$

\section{FACTURA CAMBIARIA}

Por el estrecho vínculo con sus análogas en soportes papel y electrónico, solo la factura cambiaria puede crearse en ambos formatos. En Perú, la normativa especial compele a añadir a la factura comercial una tercera copia para su transferencia a terceros o su cobro ejecutivo, denominada factura negociable, que se tiene en el art. $2^{\circ}$ como el "título valor a la orden transmisible por endoso que se origina en la compraventa u otras modalidades contractuales de transferencia de propiedad de bienes o en la prestación de servicios e incorpora el derecho de crédito respecto del saldo del precio o contraprestación pactada por las partes". ${ }^{32}$ Ahí negociable también equivale a cambiaria.

Exige el art. $3^{\circ}$ contener al menos la denominación de Factura Negociable; firma y domicilio del proveedor de bienes o servicios, a cuya orden se entiende emitida $_{i}$ domicilio del adquirente del bien o usuario del servicio, a cuyo cargo

un certificado reconocido y generada por un dispositivo seguro de creación de la firma, e incluso equivale a la firma manuscrita.

30 Cfr. Ley n. ${ }^{\circ} 19.983$, cit., art. $9^{\circ}$.

31 Vid. ZeIDA María SolarTe-AZTAíza et al., "Plataforma para servicios de facturación y pago en ambientes ubicuos", Revista Ingeniería y Universidad, Pontificia Universidad Javeriana, 13:1 (2009): 164 .

32 Ley n. ${ }^{\circ} 29623$, Ley que promueve el financiamiento a través de la factura comercial, Diario Oficial El Peruano, de 7 de diciembre de 2010. A propósito, allí acepta Correa que el cometido de la norma jurídica es ampliar el tráfico comercial del país, posibilitando un mayor acceso al crédito a quienes se les dificulta esta opción, y Echaiz opina que ofrece una oportunidad de financiamiento viable y eficiente, sobre todo para las micro y pequeñas empresas, con presencia considerable en ese territorio y un importante impacto socioeconómico. Vid. CÉSAR LUIS CORREA ZÚNĩIGA, La factura negociable y sus limitaciones a la libre circulación (tesis de maestría, Pontificia Universidad Católica del Perú, 2014), 9 y 10, y Daniel EChaiz MORENO, "La factura negociable: a propósito de su reciente creación en el Perú", Revista VIA IURIS, Fundación Universitaria Los Libertadores, 11 (2011): 47. 


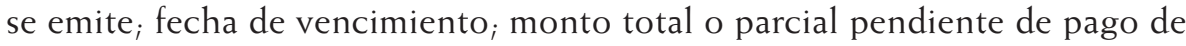
cargo del adquirente del bien o usuario del servicio; fecha de pago; fecha y constancia de recepción de la factura, así como de los bienes o servicios prestados; y la leyenda Copia transferible-no válida para efectos tributarios.

Para la aceptación, impugnación o reclamación concede el art. $7^{\circ}$ al adquiriente o usuario un término de 8 días, a partir de la recepción de la factura, vencido el cual se presume su aceptación irrevocable, al igual que el art. 8 permite transferir la factura por endoso, previa aceptación expresa o presunta, de ahí que junto a su condición de título valor ${ }^{33}$, a la factura cambiaria resultan inherentes el crédito ${ }^{34}$ y la cesión de este ${ }^{35}$, presentes en los instrumentos legales que siguen.

33 Acorde a Garrigues, se contrae a "ciertos documentos cuyo valor, estando representado por el derecho al cual se refiere (...), es inseparable del título mismo"; y a su vez, Sánchez Calero afirma ser "el documento esencialmente transmisible, necesario para ejercitar el derecho literal y autónomo en él mencionado". Para Rengifo y Nieto posee los atributos de literalidad, al guardar relación el documento con el texto que a él se incorpora, configurando el título y también el derecho; la necesidad -o legitimación-comporta que únicamente al exhibirse el documento con el derecho incorporado, es que puede exigirse la prestación cambiaria y la autonomía, en razón de la independencia de las partes intervinientes en la circulación del documento.

Así la factura cambiaria se une a títulos valores como la letra de cambio, el cheque, el pagaré, la acción, la carta de porte, la tarjeta de crédito, el conocimiento de embarque y otros, por demás tenidos como mecanismos idóneos para la cesión de créditos, que el autor del presente artículo subdivide en originaria -producida directamente desde la factura cambiaria, por contener el crédito mismo-y derivativa, por el hecho de acudirse al endoso inicial o subsiguientes en los títulos que lo permitan. Vid. JOAQUín GARRIGUES, Curso de Derecho Mercantil, (Ciudad México: Editorial Porrúa, 9a ed., 1993), 61; FERNANDO SÁNCHEZ CAlero, op. cit., 57; y RAmiro Rengifo y Norma Nieto Nieto, "Literalidad, necesidad, autonomía: atributos de los títulos valores. Análisis de la jurisprudencia de las cortes constitucional y suprema de justicia colombianas 1992-2008", Revista de Derecho, Universidad del Norte, 33 (2010): 125, 138, 146 y 147.

34 Del latín creditum, creer, confiar, prestar. Derecho de orden monetario que le compete al acreedor contra su deudor; también el valor más líquido que existe, incluido en el patrimonio de las personas naturales y jurídicas; además supone la adquisición del dominio de una cosa, o empezar a estar obligado a su restitución. Vid. DrobNIG ULRICH, "Presente y futuro de las garantías reales y personales. Informe general", Revista Latinoamericana de Derecho, Universidad Nacional Autónoma de México, 1 (2004): 133; AlejANDro GuZmán Brito, "El concepto de crédito en el Derecho chileno", Revista de Derecho, Universidad Católica del Norte, 21:2 (2014): 443; y MARTHA GARCía MANDALONIZ, "La cesión de créditos en el nuevo Código Mercantil: adecuación a las exigencias de la moderna economía crediticia", en Estudios sobre el futuro Código Mercantil. Libro bomenaje al profesor Rafael Illescas Ortiz, ed. MARÍA José MORILLAS (Madrid: Universidad Carlos III de Madrid, 2015), 87-89.

35 Existe cesión de créditos cuando una parte (acreedor) traslada a otra el derecho que le compete contra su deudor; el medio a través del cual deberán ser transferidos los créditos

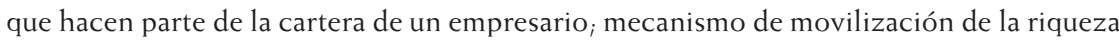
que concibe al acreedor desde una perspectiva dinámica, tenido el crédito como un bien objeto del tráfico jurídico que responde a distintas finalidades económicas. Vid. MARía EliSA CAMACHO LÓPEZ, "Problemáticas jurídicas del contrato de factoring, asociadas a su 
Colombia unifica la factura mediante Ley específica ${ }^{36}$, al atribuirle el carácter de título valor en su artículo 1, e ipso facto se considera factura cambiaria, librada por el vendedor o prestador del servicio, a remitir al comprador o beneficiario, se confecciona en original y dos copias, y el primero, firmado por ambas partes ${ }^{37}$, será negociable por endoso del emisor. Su aceptación por el destinatario (art. $2^{\circ}$ ) es expresa, bien por escrito colocado en el cuerpo de la factura o en documento separado, físico o electrónico. Es irrevocablemente aceptada (inciso $3^{\circ}$ ) si no se reclama al emisor, sea mediante devolución de la misma y de los documentos de despacho, según el caso, o mediante reclamo escrito dirigido al emisor o tenedor del título, dentro de los tres días hábiles siguientes a su recepción.

Contiene según el art. $3^{\circ}:$ "...1. La fecha de vencimiento (...) En ausencia de mención expresa en la factura de la fecha de vencimiento, se entenderá que debe ser pagada dentro de los treinta días calendario siguientes a la emisión. ${ }^{38}$

construcción dogmática a partir de la figura de la cesión de créditos", Revista E-Mercatoria, Universidad Externado de Colombia, 10:1 (2011): 6; CARLOS AlBERTO GHERSI, Contratos civiles y comerciales, (Buenos Aires, Editorial Astrea, t.I, 1998), 504; y Luz MARía RodRÍGUEZ MANTECAS, La cesión de créditos en el comercio internacional (tesis doctoral, Universidad Carlos III de Madrid, España, 2015), 31.

36 Resulta la Ley n. ${ }^{\circ} 1231$, modificados sus art.2.3, 7 y 8 por los respectivos art. 86 al 88 de la Ley n. ${ }^{\circ} 1676$. Cfr. Ley n. ${ }^{\circ} 1231$, Por la cual se unifica la factura como título valor como mecanismo de financiación para el micro, pequeño y mediano empresario, y se dictan otras disposiciones, Diario Oficial n. ${ }^{\circ} 47.053$ Colombia, de 17 de julio de 2008 ; y Ley n. ${ }^{\circ} 1676$, Por la cual se promueve el acceso al crédito y se dictan normas sobre garantías mobiliarias, Diario Oficial n. ${ }^{\circ} 48.888$ Colombia, de 20 de agosto de 2013.

37 En una posición meridiana, la Corte Constitucional colombiana consideró que: "5.2. Regla de decisión. El mero membrete de una sociedad, preimpreso en el formato de documentos denominados facturas, sin firma del creador del documento o sin la presencia de un signo o contraseña impuesto al documento, no satisface las exigencias previstas en la ley comercial para que el documento pueda ser tenido como título valor". Cfr. Sentencia T-727/13 de la Corte Constitucional de la República de Colombia, 17 de octubre de 2013, expediente T-3.870.924, http://www.corteconstitucional.gov.co/relatoria/2013/T-727-13. htm [consultado el 9 de marzo de 2018]

38 La misma instancia judicial asumió esta posición: "VI. Consideraciones y fundamentos (...) 21. Así pues, en el tercer cargo relativo a la posibilidad de vencimiento de la factura cuando esta no lo contempla expresamente, y dirigido contra el numeral $1^{\circ}$ del artículo $3^{\circ}$ de la Ley 1231 de 2008, se describe que para el evento en que la factura no dice nada en relación con el vencimiento de la misma, el plazo para generar la obligación del pago es de treinta (30) días después de emitida. Ello, vulneraría el principio de autonomía negocial de los comerciantes, y así la eficacia del reconocimiento y ejercicio (en cuanto a la libre empresa) de la personalidad jurídica (arts. 14 y 333 C.N.) Los intervinientes en su mayoría y el Ministerio Público se remiten a afirmar que tal vulneración no existe, porque quienes suscriben la factura pueden pactar cualquier cosa en cuanto a la fecha de vencimiento. En lo anterior la Sala no encuentra discusión alguna de orden constitucional, pues como se advirtió, los argumentos pasan de describir una situación a concluir que ello es contrario a la Constitución pero, no presentan razones para justificar la vulneración." Cfr. Sentencia C-852/09 de la Corte Constitucional de la República de Colombia, 25 de noviembre de 2009, expediente D-7657, http://www.mincit.gov.co/loader.php?1Servicio=Documento 
2. La fecha de recibo de la factura, con indicación del nombre, o identificación o firma de quien sea el encargado de recibirla (...) 3. (...) el prestador del servicio, deberá dejar constancia en el original de la factura, del estado de pago del precio o remuneración y las condiciones del pago si fuere el caso. A la misma obligación están sujetos los terceros a quienes se haya transferido la factura...". Precisa el art.7.1 que toda retención de la factura o acto del comprador del bien o beneficiario del servicio que impida la libre circulación de la misma, constituye una práctica restrictiva de la competencia.

Destaca el código comercial boliviano (Decreto-Ley n. ${ }^{\circ}$ 14379) en su art. 717 la figura de la factura cambiaria, título valor a los efectos exclusivos de la compraventa de mercaderías a plazo, librada a cargo del vendedor, el que la remite al comprador para que sea devuelva ya aceptada, reflejando el art. 719 en lo fundamental, la mención de Factura cambiaria de compraventa ${ }_{;}$nombre

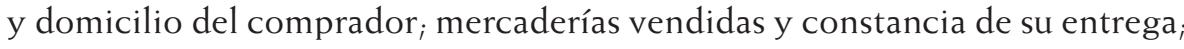
precio unitario y valor total, y la expresión en letras, en sitio visible, de ser asimilable en sus efectos a la letra de cambio.

La aceptación de la factura cambiaria obliga al comprador a su pago en el plazo previsto, conforme al art. 718 ; y por el contrario, concurre la falta de aceptación del art. 721 de no devolverse el documento negociable dentro de los cinco días posteriores a su recibo. También procede su expedición a la orden y transmisión por endoso, con la consiguiente entrega en sí del título, según el art. 520.

La Ley chilena ${ }^{39}$ la designa factura cedible, que con arreglo al art. $1^{\circ}$, en ocasión de operaciones de compraventa, prestación de servicios o actividades similares, se emite por el vendedor o prestador una copia del original, sin valor tributario, con el ánimo de cederla a terceros o de cobro ejecutivo.

En relación, el art. $4^{\circ}$ regula su aptitud para cederla si se expide conforme a las normas de la factura original, agregada en su cuerpo la mención cedible; y si consta el recibo de las mercaderías o del servicio, indicación del recinto, fecha de la operación, nombre completo, rol único tributario y domicilio del comprador o cliente, e identificación y firma de quien recibe, permitiendo además la parte final del precepto su vocación circulatoria.

Además la factura se reputa aceptada de no reclamarse dentro de los ocho días corridos siguientes a su recepción, o en su defecto, en otro plazo acordado por las partes, sin que exceda de treinta días corridos $\left(\operatorname{art.~} 3^{\circ}\right)_{i}$ el pago se exige al momento, a un plazo o a un día fijo $\left(\operatorname{art} .2^{\circ}\right)_{i}$ y al reconocer la factura virtual, permite que emisor y receptor, por ese orden, puedan recibir el pago o las mercancías haciendo uso de la firma electrónica, como igual será por medios electrónicos la cesión del crédito presente en el instrumento (art. $9^{\circ}$ )

s\&lFuncion $=$ verPdf\&id $=21289 \&$ name $=$ SentenciaC $-852-09$. pdf\&prefijo $=$ file $[$ consultado el 9 de marzo de 2018] 
No menos importante, la normativa establece que el cedente debe firmar en el anverso de la copia cedible, acto este traslaticio de dominio a comunicar al obligado al pago, a través de notario público o en su defecto, del oficial de Registro Civil en las comunas, sea de forma personal, exhibiendo copia del título o por envío de carta certificada a cargo del cesionario $\left(\operatorname{art} .7^{\circ}\right) .^{40}$

Si bien España ofrece regulación a la factura electrónica, pudo dotarse de carácter cambiario desde ese formato, pero no se autoriza en la Ley n. ${ }^{\circ} 59$, pues su naturaleza misma virtual los priva de validez como títulos valores a causa de la unicidad y "por la posibilidad (y enorme facilidad) de copia de los documentos electrónicos, sin que se pueda distinguir entre original y copia". ${ }^{41}$

En la doctrina española además Madrid apunta a legitimar al documento electrónico transferible -la factura virtual entre ellos-, de modo que mediante él, la persona que controla exige cumplirse la obligación contenida y permitirse traslade ese mismo derecho; optándose así, en cuanto al titular del derecho, por el término persona que ejerce el control en sustitución del tradicional tenedor del documento en papel. ${ }^{42}$

En fin, la factura cambiaria, negociable, cedible o transferible tiene un beneficio agregado, dado que su aceptación le atribuye en el acto el carácter de título valor, le imprime dinamismo el documento al ser posible su circulación y garantiza el cumplimiento de obligaciones pecuniarias.

\section{UTILIDAD DE LA FACTURA, A TRES DIMENSIONES}

El empleo de la factura por empresarios y otros sujetos confiere seguridad jurídica a los distintos pactos que tienen lugar en el mercado, al tiempo de advertirse su utilidad en las dimensiones comercial, contable y tributaria.

40 Comenta Selman, a raíz de un fallo del máximo órgano judicial chileno, que se desestimó el recurso de casación con el argumento de que "La notificación de la cesión del crédito de una factura debe realizarse -necesariamente- de forma personal al deudor, resultando insuficiente aquella efectuada mediante carta certificada emitida por un notario público", lo que entendió un desacierto, pues "(...) de todas maneras tal discusión resulta aplicable a un contexto diverso al discutido aquí, ya que las facturas objeto de revisión de la sentencia en comento, fueron extendidas y cedidas en el año 2008, es decir, 4 años después de que entrara en vigencia la referida Ley". Vid. Arturo Selman Nahum, "Cesión de créditos contenidos en una factura y la notificación personal al deudor como requisito excluyente para su oponibilidad: Un fallo inquietante (Corte Suprema)", Revista de Derecho, Universidad de Valdivia, 25:2 (2012): 296 y 297; y Sentencia de la Corte Suprema de Chile, 10 de mayo de 2011, causa Rol n. ${ }^{\circ}$ 26-2010.

41 Francisca Hinarejos Campos, José Luis Ferrer Gomila, y Apolonia Martínez Nadal, "Letras de cambio, cheques y pagarés electrónicos; aproximación técnica y jurídica", Revista IUS, Instituto de Ciencias Jurídicas de Puebla A.C., 7:31 (2013): 232.

42 Agustín MAdRID PARRA, "Avances de Naciones Unidas en la regulación de los documentos electrónicos transferibles", en Estudios sobre el futuro Código Mercantil. Libro bomenaje al profesor Rafael Illescas Ortiz, ed. María José MoriLlas (Madrid: Universidad Carlos III de Madrid, 2015), 2076. 
Resalta en el lado comercial que la factura es un documento cada vez más extendido en los negocios, de expedición obligatoria, según leyes consultadas, cual reflejo de actos contractuales propios del mercado, con destaque para la compraventa y los servicios. Así mismo, se tiene a la factura como el soporte por excelencia del crédito, y por consiguiente, ella es clave en toda pretensión de cederlo.

Otra arista se contrae a su valor probatorio de los actos mercantiles, respecto a lo cual Lara refiere que "por principio, la factura vincula a quien la emite y su contenido hace prueba frente al autor de las declaraciones que figuran en ella; aunque tampoco puede eludir sus efectos quien, sin haberla emitido, pretenda hacerla valer frente a otros ${ }^{\prime \prime 4}$; tal cual se reconoce en el espacio mexicano. ${ }^{44}$

Como muestra de su regulación, el Código salvadoreño ${ }^{45}$ estipula en el art. 999.II que las facturas prueban obligaciones mercantiles y su extinción, postura muy similar a la contenida en las leyes nicaragüense ${ }^{46}$ y panameña ${ }^{47}$, al exigir sus respectivos art. 111 (letra d) y 244.4 que sea mediante facturas aceptadas.

En cuanto al Código argentino, a falta de referencia expresa de la factura para probar los contratos, cabe presumirse de la interpretación extensiva del art. 1020: "(...) Los contratos en los cuales la formalidad es requerida a los fines probatorios pueden ser probados por otros medios, inclusive por testigos, si hay imposibilidad de obtener la prueba de haber sido cumplida la formalidad o si existe principio de prueba instrumental, o comienzo de ejecución. Se considera principio de prueba instrumental cualquier instrumento que emane de la otra parte, de su causante o de parte interesada en el asunto, que haga verosímil la existencia del contrato." ${ }^{48}$

Vid. Rafael lara González, op. cit., 2035.

"Considerando Primero: (...) los elementos en mención quedaron plenamente demostrados con las diez facturas, que acompañó el accionante al escrito inicial de demanda, expedidos por la demandada (...) a favor de la (...) por la cantidad total de (...), documentales que producen plenos efectos probatorios, al tenor de lo dispuesto por el artículo 1296 del Código de Comercio, toda vez que no obstante que fueron redargüidas de falsas, sin embargo la parte demanda [demandada], no acreditó dicha objeción como más adelante se indicará, ello así resulta porque en las facturas que son base del presente juicio, claramente se advierte el nombre y firma de una persona de nombre (...), mediante el cual manifiesta que recibió el original de dichas facturas para el trámite de pago". Cfr. Sentencia Definitiva Mercantil n. ${ }^{\circ} 454 / 2015$ del Distrito Judicial de Saltillo, México, 30 de noviembre de 2015, expediente 2034/2015, http://pjec.gob.mx/sentencias/571SP4542015.pdf [consultado el 9 de marzo de 2018]

Cfr. Código de Comercio, Diario Oficial n. ${ }^{\circ} 1140$ El Salvador, de 31 de julio de 1970.

Cfr. Código de Comercio de Nicaragua, cit.

Cfr. Ley n. ${ }^{\circ} 2$, cit.

Cfr. Ley n. ${ }^{\circ} 26.994$, cit. 
Igual se carece de regulación expresa de la factura en territorio brasileño, aunque se colige del art. 212.II, disponiendo que los actos jurídicos se probarán mediante documento, excepto que el negocio requiera de forma especial. ${ }^{49}$

En su dimensión contable, la factura, a la par de contener datos de repercusión legal, también refleja hechos de significación económica, objeto de anotación en los libros del emisor (acreedor) y el destinatario (deudor).

Es una regularidad en los códigos comparados exigir a los empresarios que intervienen en actos de comercio su registro contable en los tradicionales libros diario y mayor ${ }^{50}$, sumados los estados financieros de inventario y balance, donde se asientan las cuentas acreedoras y deudoras con sus saldos, además de adjuntarse los documentos que lo respalden, las facturas entre ellos.

Tratándose de normativas especiales, están las promulgadas en Colombia y España. Se expuso que la nación latina unificó la factura en condición de título valor, a emitirse en original y dos copias, que destinatario y emisor llevarán a sus respectivos registros contables. ${ }^{51}$ En suelo español los sujetos de la Ley crean el registro contable de facturas para su seguimiento, que como registro se integre con el sistema de información contable..$^{52}$

La vertiente tributaria de la factura descansa en la relevancia de su contenido para el control del Fisco, pues como documento evidencia la generación de ingresos de su emisor y los gastos atribuibles al receptor, de ahí que sea "una de las herramientas de información con que cuenta la administración tributaria para ejercer un control efectivo sobre el cumplimiento de los deberes tributarios (...) y al unísono es requisito para la aplicación de deducciones del impuesto sobre el valor añadido. ${ }^{53}$

Con la emisión de la copia de la factura surgen dos circunstancias de índole tributaria en la mentada Ley n. ${ }^{\circ} 19.983$ chilena, pues por un lado, la factura original soporta operaciones comerciales gravadas, que comportan obligaciones para los contratantes en su status de contribuyentes, mientras que tratándose de la copia que precisa el art. 1, solo para transferencia a terceros o cobro ejecutivo y carente de valor tributario (evitar la doble imposición fiscal), en virtud del art. 9, si el documento está en formato electrónico, el cedente dará conocimiento al obligado al pago por medio de su anotación en un registro

49 Su redacción literal es: "Artigo 212. Salvo o negócio a que se impõe forma especial, o fato jurídico pode ser provado mediante: (...) II-documento". Cfr. Ley n. ${ }^{\circ} 10.406$, Instituye el Código Civil, Diario Oficial de Brasil, de 11 de enero de 2002.

50 Cfr. Decreto-Ley n. ${ }^{\circ} 14379$, art. 44; Código de Comercio de Nicaragua, art. 28; Código de Comercio de El Salvador, art. 435; Ley n. ${ }^{\circ}$ 26.994, art. 321; Código de Comercio de Venezuela, art. 32; y Ley n. ${ }^{\circ} 2$, art. 71. 
público electrónico de transferencias de créditos, a cargo del Servicio de Impuestos Internos.

Con igual finalidad se promulgó en Perú la Ley n. ${ }^{\circ} 29623$ citada, que exige del emisor incorporar una tercera copia de la factura comercial o en papel con fines de su negociabilidad, sea para transferirla a terceros o proceder a su cobro ejecutivo, proceso signado por la intervención de la Superintendencia Nacional de Administración Tributaria (SUNAT), órgano estatal que por el art. 3 decide el contenido de la factura comercial y de su tercera copia, con independencia a que la última no tenga validez tributaria.

Respalda la apreciación de la factura como "piedra angular en la gestión del tributo $^{\prime \prime 5}$ español su máxima ley fiscal ${ }^{55}$, en especial el art. 29, letra e, relativo a la obligación de los contribuyentes de "expedir y entregar facturas o documentos sustitutivos y conservar las facturas, documentos y justificantes que tengan relación con sus obligaciones tributarias", además de la justificación prioritaria por empresarios o profesionales, mediante factura, de los gastos deducibles y las deducciones practicadas en relación a las operaciones realizadas (art. 106)

Se adicionan preceptos sobre el control fiscal de los acuerdos de simplificación de la obligación de facturar, siempre que tenga trascendencia tributaria (art. 117); la comprobación limitada de obligaciones tributarias en base al examen de facturas que justifiquen operaciones incluidas en libros y registros contables (art. 136); y la inspección tributaria mediante el análisis de las facturas y otros documentos a facilitar a la SUNAT, o necesarios para exigir obligaciones (art. 142)

Téngase por válido que la factura controlada por los empresarios coadyuva en principio al acatamiento de la disciplina fiscal exigida desde su posición de contribuyentes, independientemente de que la hacienda pública esté investida de la potestad legal de supervisión de las obligaciones tributarias.

Aunque seguida una lógica en el planteamiento de las utilidades de la factura a tres dimensiones, se evidencia que estas guardan estrecha relación entre sí, como se manifiesta en situaciones fácticas como las siguientes: una, la factura de una operación mercantil se registra contablemente por el empresario, pero a su vez desde su misma emisión existen exigencias tributarias, al poder determinar de su contenido el hecho y la base imponibles, que permitan exigir los impuestos procedentes; $;$ y dos, que desde los asientos en los libros de la contabilidad, combinado con otros medios, se puede probar la realización del acto mercantil.

Reconocidos los avances normativos sobre la factura en Iberoamérica, asimismo se presentan irregularidades técnicas, en interés de afrontarlas en

54 Vid. IsAbel SÁnCHEZ SeREnA, "La factura electrónica en España", Revista de Internet, Derecho y Política, Universidad de Cataluña, 13 (2012): 5.

55 Cfr. Ley n. ${ }^{\circ}$ 58, Ley General Tributaria, Boletín Oficial del Estado n. ${ }^{\circ} 302$ España, de 18 de diciembre de 2002. 
su desarrollo legislativo en Cuba, dadas en el empleo único de la factura en el contrato de compraventa (Nicaragua, Panamá, Venezuela y Ecuador), la restricción en Bolivia para la circulación de la factura, que afecta su vocación cambiaria $;$ y las dificultades que acarrea en Chile la notificación al deudor en la factura cedible, en ocasión del endoso, sin obviar que apenas España incorpora en ley exigencias tecnológicas ante el riesgo de que la factura electrónica se reproduzca de mala fe.

\section{LA FACTURA DESDE EL CONTEXTO CUBANO}

La mirada a la factura allende las fronteras sirvió de antesala para escudriñar su manifestación en las vertientes teórica, normativa y práctica del contexto de Cuba, país que actualiza su modelo económico e igual se ubica en el área iberoamericana. Careciéndose de estudios específicos sobre la factura, en su defecto los nacionales Montes de Oca y Boyle ${ }^{56}$ la tratan indirectamente con motivo de investigaciones sobre el contrato de factoring o factoraje.

Desde el vértice legal se aprecia que no precisamente la factura goza de autonomía comercial en sí, que la provea de la configuración requerida a los fines del mercado, transferibilidad incluida ${ }^{57}$. En su lugar, está implícita en la actividad económica lato sensu, sin importar qué sujetos intervienen. ${ }^{58}$

Faltando una definición de la factura en el código comercial vigente ${ }^{59}$, que por vocación debió acogerla, sus art. 754, 766 y 776 le asignan carácter probatorio de la determinación del valor de las cosas objeto del contrato de seguro marítimo y de la compra y valor de mercancías aseguradas, que se perdieran en el mar. Mientras que el Tribunal Supremo Popular en su Dictamen

56 Vid. Lidia MOnTES DE OCA HeRnÁndEZ, "El contrato de factoring. Importancia de su aplicación en Cuba", Revista Boletín ONBC, Organización Nacional de Bufetes Colectivos de Cuba, 31 (2008): 14-16; y Manuel Boyle PACHECO, "Contratos financieros", en Temas de Derecho Mercantil cubano, ed. NATACHa Mesa Tejeda (La Habana: Editorial Félix Varela, t.II, 2005), 74.

57 Solo se reconocen en Cuba estos títulos valores: letra de cambio, cheque, pagaré y carta de crédito. Cfr. Código de Comercio de Cuba, cit., art.567-572; Decreto-Ley n. ${ }^{\circ} 341$, De la letra de cambio, el pagaré y el cheque, Gaceta Oficial Ordinaria n. ${ }^{\circ} 7$ Cuba, de 9 de febrero de 2017; y Resolución n. ${ }^{\circ} 101$, art.1-13 y 16-18.

58 Coexisten una variedad de sujetos, con protagonismo para la empresa estatal, que junto a la unidad presupuestada conforman el sector público, mientras que de carácter privado están el trabajador por cuenta propia, artistas independientes, agricultores individuales, cooperativas (agropecuarias o no), y sociedades mercantiles (cubanas, mixtas y de capital totalmente foráneo) Cfr. Decreto Ley n. ${ }^{\circ}$ 304, De la contratación económica; y Decreto n. ${ }^{\circ} 310$, De los tipos de contratos, ambos en Gaceta Oficial Ordinaria n. ${ }^{\circ} 62$ Cuba, de 27 de diciembre de 2012.

59 Cfr. Código de Comercio de Cuba, Real Decreto de la Corona Española, de 28 de enero de 1886. 
n. ${ }^{0} 426^{60}$ atribuyó a la factura el carácter de documento comercial ${ }^{61}$, basado en su "uso común en el tráfico jurídico-mercantil (...) para hacer constar y dejar evidencia de las operaciones mercantiles que dan lugar a esta", llevada a controles contables, sin que satisfaga los requisitos de título valor.

Apenas existe la modalidad de factura en papel, de manera que están reguladas la prefactura, la factura propiamente dicha y la factura comercial, diferencia que estriba en la finalidad. Con el documento inicial ${ }^{62}$ (Modelo SC.2.21) se crean las condiciones para autorizar la posterior adquisición de productos y la prestación de servicios, según el caso, y que el comprador cliente pueda proceder a su pago. ${ }^{63}$

A su vez, la factura (Modelo SC.2.12), de carácter obligatorio, se emplea para "formalizar las ventas de productos y prestaciones de servicios que se efectúen, así como las entregas de productos en consignación o en depósito, que no son sujetas de la factura comercial (...) además, para formalizar las ventas de activos fijos tangibles y de productos para efectuar devoluciones". ${ }^{64}$ En cuanto a la factura comercial ${ }^{65}$ (Modelo SC.2.18), es útil para similares operaciones que la factura, solo que de tipo mayorista, cuando se trata de una persona jurídica suministradora-prestadora, principalmente de los sectores alimentario e industrial.

60 Cfr. Dictamen n. ${ }^{\circ}$ 426, Tribunal Supremo Popular de la República de Cuba, Gaceta Oficial Ordinaria n. ${ }^{\circ} 35$, de 7 de septiembre de 2009.

61 Antes y después del Dictamen, la alta instancia judicial se ha pronunciado sobre el carácter comercial de la factura, valor probatorio, utilidad contable y otras cuestiones. Cfr. Sala de lo Económico del Tribunal Supremo Popular de la República de Cuba, Sentencias n. ${ }^{\circ} 21,28$ de junio de 2007, en expediente n. ${ }^{\circ} 177$, , n. ${ }^{\circ} 222,29$ de noviembre de 2013, en expediente n. ${ }^{\circ} 234 ;$ n. ${ }^{\circ} 49,31$ de marzo de 2014 , en expediente $n .{ }^{\circ} 54 ;$ n. ${ }^{\circ} 150,30$ de septiembre de 2015 , en expediente n. ${ }^{\circ} 158$; y n. ${ }^{\circ} 178,30$ de septiembre de 2016 , en expediente n. ${ }^{\circ} 192$; y de la Sala de lo Penal, Sentencia n. ${ }^{\circ} 3140,7$ de noviembre de 2014, en causa n. ${ }^{\circ} 114$.

62 Cfr. Resolución n. ${ }^{\circ}$ 259, Ministerio de Finanzas y Precios, Gaceta Oficial Extraordinaria n. ${ }^{\circ} 44$ Cuba, de 15 de diciembre de 2008.

63 Una manifestación práctica está en la entidad comercializadora mayorista Corporación CIMEX S.A., en particular sus sucursales, donde expiden la prefactura. Luego su contraparte emite el cheque, que presenta al momento de extraer la mercancía de los almacenes del proveedor, y si su valor es inferior al que consta en el instrumento de pago, entonces se acuerda que el saldo restante queda en crédito comercial a favor del cliente, produciéndose una traslación transitoria de la posición de los contratantes, de manera que la sociedad suministradora-vendedora, ante el pago imprevisto, pasa a ser deudora del suministradocomprador, devenido en acreedor mientras no se cumpla la obligación de entregarle los productos pendientes.

64 Cfr. Resolución n. ${ }^{\circ}$ 11, Ministerio de Finanzas y Precios, Gaceta Oficial Ordinaria n. ${ }^{\circ} 15$ Cuba, de 12 de febrero de 2007

65 Cfr. Instrucción n. ${ }^{\circ}$ 15, Ministerio de Finanzas y Precios, Gaceta Oficial Ordinaria n. ${ }^{\circ} 67$ Cuba, de 6 de septiembre de 2006. 
Conforme a la Resolución n. ${ }^{\circ} 11$ y la Instrucción n. ${ }^{\circ} 15$ abordadas, la factura se presenta en formato papel ${ }^{66} \mathrm{y}$ se digitaliza, que no significa modalidad electrónica, puesto que, si bien se soporta en sistemas informáticos -entre ellos VERSAT, CÓNDOR, SISCONT, CONEC y ASSET-, facilitando en sus ficheros la conformación, emisión e impresión de facturas, técnica y normativamente no puede transferirse vía electrónica, a causa de inexistir mecanismos como la firma y los mensajes de datos, solo posible en la actualidad en el sistema bancario, para la transferencia de fondos entre sucursales, cual manifestación de e-commerce. ${ }^{67}$

Otra expresión por medios telemáticos es la factura telefónica de la Empresa de Telecomunicaciones de Cuba S.A. (ETECSA) ${ }^{68}$ constituida en plataforma digital facilitadora de información comercial al cliente, previa introducción de su código para consultar el débito del periodo, careciendo también de las prestaciones de la firma electrónica y los mensajes de datos, dable si se cuenta con la infraestructura tecnológica apropiada.

La utilidad mercantil de la factura en Cuba reside en el valor probatorio de las operaciones que refleja, destacando en el Decreto n. ${ }^{\circ} 310$, art. 4, la obligación del vendedor de entregar al comprador los documentos relacionados con el contrato, que según art. 31 puede ser aplicable a otras figuras, como el transporte terrestre de carga y la ejecución de obra, previstos por ese orden en los art. 126 y 179.

Legitima el Decreto-Ley n. ${ }^{\circ}$ 304, art. 31, las opciones de concertar el contrato de forma escrita o verbal, sin embargo la Resolución n. ${ }^{\circ} 11$ obliga a emplear documentos vinculados a la factura-solicitudes de compra o servicio, informe de recepción, vale de entrega o devolución, orden de despacho, conduce, carta de porte, instrumentos de pago, submayor de inventario, tarjeta de estiba, y remisión de salida del puerto- de los que en situaciones coyunturales se valdrán las partes para presumir la existencia de la relación contractual .

66 La Resolución n. ${ }^{\circ} 11$ ha tutelado el empleo de la factura en los pactos entre personas jurídicas, empero, dentro del proceso actualizador del modelo económico cubano, se autorizó en 2011 a su emisión por los trabajadores por cuenta propia bajo estas condiciones de la Instrucción n. ${ }^{\circ}$ 7: "1. La comercialización de los productos o servicios de los trabajadores por cuenta propia a las entidades estatales (incluidas las unidades presupuestadas) y sociedades mercantiles de capital totalmente cubano, debe realizarse a través de contratos, ya sean verbales o escritos (...) 3. Pueden concertarse contratos verbales en los que será suficiente con la factura o documento que acredite el servicio prestado y la cuantía a pagar". Cfr. Instrucción n. ${ }^{\circ}$, Indicaciones a las entidades estatales para la contratación de los productos y servicios de los trabajadores por cuenta propia, Ministerio de Economía y Planificación, Gaceta Oficial Extraordinaria n. ${ }^{\circ} 40$ Cuba, de 21 de noviembre de 2011.

67 Cfr. Resolución n. ${ }^{\circ}$ 101, Normas bancarias para los cobros y pagos, Banco Central de Cuba, Gaceta Oficial Extraordinaria n. ${ }^{\circ}$ 40, de 21 de noviembre de 2011.

68 Vid. EMPRESA DE TeleCOMUniCACIONES DE CuBA S.A., "Factura telefónica", 2018, http:www. etecsa.cu/telefonía_fija/factura_telefónica [consultado el 10 de febrero de 2018] 
La tendencia en la praxis del país es dotar a los tratos de seguridad jurídica a través de su celebración escrita, aunque en ciertas circunstancias se salta esta ritualidad, como sucede con las Empresas de Transporte de Cargas (EMCARGA) y de Transporte por Contenedores (TRANSCONTENEDORES), que asumen el traslado eventual de mercancías si se imposibilita cumplir con los niveles planificados de tráfico diario, y si bien el acuerdo es verbal, en propiedad se presume con los documentos que amparan la carga, de control en almacenes y de pago del servicio normados en la Resolución n. ${ }^{\circ} 11$ antes dicha.

Dentro el contenido de la factura se evidencian hechos o actos de trascendencia contable, que debidamente registrados le facilitan a emisor y destinatario información de utilidad en la gestión del negocio. A lo interno, la factura se enumera consecutivamente por el área o departamento contable de la parte que la expide, en consonancia con la Resolución n. ${ }^{\circ} 235^{69}$, modificada por la Resolución n. ${ }^{\circ} 472^{70}$, sobre el nomenclador de cuentas nacionales.

En consecuencia, se realizan los asientos contables según la naturaleza acreedora o deudora de la cuenta: el emisor de la factura registra su activo en las cuentas 135-Cuentas por cobrar a corto plazo, 334-Cuentas por cobrar diversas y 430-Cobros anticipados; a su vez el cliente anota su pasivo en las cuentas $146-\mathrm{Pa}$ gos anticipados a suministradores, 405-Cuentas por pagar a corto plazo y 421-Cuentas por pagar activos fijos tangibles.

Sobre la factura y su repercusión en la dimensión tributaria, valorado el cuerpo legal vigente ${ }^{71}$, resalta su utilidad para la actuación de la Oficina Nacional de Administración Tributaria (ONAT), como también facilita a los contribuyentes la información de índole económica de la que se originan sus deudas tributarias. De la Ley n. ${ }^{\circ} 113$, el art. 393 establece la asunción por los contribuyentes de los deberes formales de "mantener en condiciones de auditabilidad o cualquier otra acción de fiscalización, por un término de cinco años, los libros de contabilidad, registros, comprobantes y demás documentos" (letra d), que incluye las facturas; y presentar similar documentación "(...) en la forma, términos y requisitos establecidos legalmente" (letra h)

Señala el Decreto n. ${ }^{\circ} 308$ en el art. 13 las funciones de control fiscal de la ONAT concernientes a "practicar la determinación administrativa de la deuda tributaria (...) mediante otras informaciones relacionadas con el hecho imponible" (letra d), y "requerir a las personas naturales y jurídicas la entrega de datos, informes y antecedentes con trascendencia tributaria, derivados de

69 Cfr. Resolución n. ${ }^{\circ} 235$, Ministerio de Finanzas y Precios, Gaceta Oficial Ordinaria n. ${ }^{\circ} 44$ Cuba, de 21 de diciembre de 2005.

70 Cfr. Resolución n. ${ }^{\circ} 472$, Ministerio de Finanzas y Precios, Gaceta Oficial Ordinaria n. ${ }^{\circ} 3$ Cuba, de 30 de enero de 2013.

71 Cfr. Ley n. ${ }^{\circ} 113$, Del Sistema Tributario, y Decreto n. ${ }^{\circ} 308$, Reglamento de las normas generales y de los procedimientos tributarios; ambos en Gaceta Oficial Ordinaria n. ${ }^{\circ} 53$ Cuba, de 21 de noviembre de 2012. 
sus relaciones económicas, profesionales o financieras con otras personas"; mientras que el art. 28 obliga a los contribuyentes a consignar el Número de Identificación Tributaria asignado en "(...) facturas u otros documentos de operaciones comerciales y financieras, que expidan por razón de sus obligaciones tributarias".

En otros aspectos, es lícito ceder créditos contenidos en factura, sobre todo en ocasión del contrato de factoring, solo que de manera derivativa, a través de los títulos valores del Decreto-Ley n. ${ }^{\circ} 341$. Para la letra de cambio, girándola a cargo del librado y a favor de un tercero, donde el librador es el acreedorcliente, el librado es el deudor y el tercero o tenedor, el factor (art. 17, letra a); o por el endoso nominativo de los art. 29 al 31: coincide el deudor, el tenedor resulta en endosante-cliente y el endosatario se torna en factor, preceptos estos supletorios para el pagaré.

Respecto al cheque que es librado por cuenta de un tercero (art. 155, letra b), figuran el librador-deudor, el librado -banco en que operan los fondos del deudor-y el tenedor-acreedor, que al ser objeto de endoso por el precepto siguiente y con fines de factoring, conlleva a que los sujetos intervinientes queden en idéntica posición que la letra de cambio.

\section{A MODO DE CONCLUSIONES}

En la legislación iberoamericana la factura resulta un documento privado inmerso en el ámbito del mercado, mayormente concebida desde los códigos comerciales, aunque sus modalidades electrónica y cambiaria alcanzan normatividad en leyes especiales; en el primer formato requerida del mensaje de datos y la firma electrónica para garantizar su integridad, con independencia a equipararse o no a la factura en papel, mientras que desde su condición de título valor le es inherente la circulación a partir del endoso, considerando el crédito contenido en la factura y su cesión futura en ocasión del contrato de factoring. Asimismo, es de considerar su utilidad en los órdenes comercial, contable y tributaria.

En el contexto cubano se adolece de la construcción teórica de la factura, inclusive está requerida de configuración normativa con carácter comercial, para posibilitar en especial su negociabilidad, dinamizando la cesión del crédito en ella nacido, que en adición a su expresión práctica a través de la intervención de la factura en actos del comercio mayorista, soportada en sistemas informático-contables y telemáticos, y para probar contratos verbales en el transporte, condicionan la necesidad de atemperarla al proceso actualizador del modelo económico patrio. 


\section{BIBLIOGRAFÍA}

Álvarez Montoya, Daniela, y Correa Patiño, Eliana Cristina. "El impacto del e-commerce en la cadena logística de las empresas importadoras de la ciudad de Medellín". Revista En-Contexto, Instituto Tecnológico de Antioquia, 6:8 (2018): 86 y 87.

Asencio Sandoval, AngIE, y Guerra Fuentes, Víctor. Procedimientos de control interno sobre la facturación para la Empresa FILIBÓN S. A. Tesis, Universidad de Guayaquil, 2016.

Boyle Pacheco, Manuel. "Contratos financieros". En Temas de Derecho Mercantil cubano, editado por NATACHA MESA TejedA. La Habana: Editorial Félix Varela, t. II, 2005.

Camacho López, María Elisa. "Problemáticas jurídicas del contrato de factoring, asociadas a su construcción dogmática a partir de la figura de la cesión de créditos". Revista E-Mercatoria, Universidad Externado de Colombia, 10:1 (2011): 6.

Carbajo VASCO, Domingo. "Hacia una reforma de la normativa europea sobre facturación en el IVA", 2010. http://www.elderecho.com/tribuna/administrativo/ reforma-normativa-europea-facturacion-IVA _11_199555002.html.

CORREA ZÚÑIgA, CÉSAR LUIS. La factura negociable y sus limitaciones a la libre circulación. Tesis, Pontificia Universidad Católica del Perú, 2014.

Delgado García, ANA MARÍA. "La regulación de la factura electrónica en el sector público". Revista de Internet, Derecho y Política, Universidad de Cataluña, 18 (2014): 98.

ECHAIZ MORENO, DANIEL. "La factura negociable: a propósito de su reciente creación en el Perú". Revista VIA IURIS, Fundación Universitaria Los Libertadores, 11 (2011): 47.

EMPRESA DE TeleCOMUniCACIONES DE CUBA S.A. "Factura telefónica", 2018. http:www. etecsa.cu/telefonía_fija/factura_telefónica.

García Mandaloniz, Martha. "La cesión de créditos en el nuevo Código Mercantil: adecuación a las exigencias de la moderna economía crediticia". En Estudios sobre el futuro Código Mercantil. Libro bomenaje al profesor Rafael Illescas Ortiz, editado por María JosÉ MorILlaS. Madrid: Universidad Carlos III de Madrid, 2015, 87-89.

Garrigues, Joaquín. Curso de Derecho Mercantil. Ciudad México: Editorial Porrúa, 9a ed., 1993.

Ghersi, Carlos Alberto. Contratos civiles y comerciales. Buenos Aires, Editorial Astrea, t.I, 1998.

GuZmán Brito, Alejandro. "El concepto de crédito en el Derecho chileno". Revista de Derecho, Universidad Católica del Norte, 21:2 (2014): 443. 
Hinarejos Campos, Francisca, Ferrer Gomila, José Luis, y Martínez Nadal, APOLONIA. "Letras de cambio, cheques y pagarés electrónicos; aproximación técnica y jurídica". Revista IUS, Instituto de Ciencias Jurídicas de Puebla A.C., 7:31 (2013): 232 .

Jurado, Alberto. "Valor probatorio del documento electrónico". Revista Cuestiones Jurídicas 5:1 (2011): 56 y 57.

LARA GONZÁLEZ, RAFAEL. "La factura en el Derecho Mercantil proyectado". En Estudios sobre el futuro Código Mercantil. Libro bomenaje al profesor Rafael Illescas Ortiz, editado por María José Morillas. Madrid: Universidad Carlos III de Madrid, 2015, 2035.

Madrid PARra, Agustín. "Avances de Naciones Unidas en la regulación de los documentos electrónicos transferibles". En Estudios sobre el futuro Código Mercantil. Libro bomenaje al profesor Rafael Illescas Ortiz, editado por MARÍA JOSÉ MORILLAS. Madrid: Universidad Carlos III de Madrid, 2015, 2076.

Martos García, JuAn Jesús. "La integridad del contenido y la autenticidad de origen en la transmisión o puesta a disposición de la factura". Revista de Internet, Derecho y Política, Universidad de Cataluña, 12 (2011): 88 y 89.

Montes de OcA HernÁndeZ, Lidia. "El contrato de factoring. Importancia de su aplicación en Cuba". Revista Boletín ONBC, Organización Nacional de Bufetes Colectivos de Cuba, 31 (2008): 14-16.

NACIONES UnIDAS. "Situación y perspectivas de la economía mundial 2018". https:// www.un.org/development/desa/dpad/wp-content/.../WESP2018essp.pdf.

Piloñeta Alonso, Luis Manuel. Curso de Derecho Mercantil de la contratación. Oviedo: Editorial Ediuno, $2^{\text {a }}$ ed., 2014.

Prado Puga, Arturo. "Alcance jurídico de la factura como título de circulación mercantil". Revista de Derecho, Pontificia Universidad Católica de Valparaiso, 46 (2016): 157 .

RenGifo, RAmiro, y Nieto Nieto, Norma. "Literalidad, necesidad, autonomía: atributos de los títulos valores. Análisis de la jurisprudencia de las cortes constitucional y suprema de justicia colombianas 1992-2008". Revista de Derecho, Universidad del Norte, 33 (2010): 125, 138, 146 y 147.

Rodríguez ChICAIZA, JESSICA GEOVANNA. La facturación electrónica vs control fiscal. Análisis comparado con las administraciones tributarias de Chile y España. Tesis, Universidad Andina Simón Bolívar, 2015.

ROdRíGUEz MANTECAS, LUz María. La cesión de créditos en el comercio internacional. Tesis, Universidad Carlos III de Madrid, 2015. 
SÁnChez Calero, Fernando. Instituciones de Derecho Mercantil. Madrid: Editoriales de Derecho Reunidas, $17^{\mathrm{a}} \mathrm{ed}$., 1994.

SÁnCHEZ SERENA, ISABEL. "La factura electrónica en España". Revista de Internet, Derecho y Política, Universidad de Cataluña, 13 (2012): 5.

Selman Nahum, Arturo. "Cesión de créditos contenidos en una factura y la notificación personal al deudor como requisito excluyente para su oponibilidad: Un fallo inquietante (Corte Suprema)". Revista de Derecho, Universidad de Valdivia, 25: 2 (2012): 296 y 297.

Solarte-Aztaíza, Zeida María, Óscar Mauricio Caicedo-Rendón, JaVier IMBUZ, y MILTON AUSECHA. "Plataforma para servicios de facturación y pago en ambientes ubicuos". Revista Ingeniería y Universidad, Pontificia Universidad Javeriana, 13:1 (2009): 164 .

ULRICH, DrobNIG. "Presente y futuro de las garantías reales y personales. Informe general". Revista Latinoamericana de Derecho, Universidad Nacional Autónoma de México, 1 (2004): 133

Zubillaga Rego, Agustín. "Informe de economía y sociedad digitales en el País Vasco", 2018. http://www.orkestra.deusto.es/euskadigitala/data/economia-sociedad-digitales-pais-vasco.pdf.

\section{LEGISLACIÓN}

Código de Comercio de Nicaragua, Gaceta n. ${ }^{\circ}$ 248, de 30 de octubre de 1916.

Ley n. ${ }^{\circ}$, Por la cual se aprueban los Códigos Penal, de Comercio, de Minas, Fiscal, Civil y Judicial, elaborados por la Comisión Codificadora, Gaceta Oficial n. ${ }^{\circ}$ 02404 Panamá, de 22 de agosto de 1916.

Código de Comercio de Venezuela, Gaceta n. ${ }^{\circ} 475$ Extraordinaria, de 21 de diciembre de 1955.

Código de Comercio de Ecuador, Registro Oficial n. ${ }^{\circ}$ 1202, de 20 de agosto de 1960

Ley n. ${ }^{\circ}$ 26.994, Código Civil y Comercial de la Nación Argentina, Boletín Oficial de 8 de octubre de 2014 .

Decreto-Ley n. ${ }^{\circ}$ 14379, Código de Comercio de Bolivia, Gaceta Oficial n. ${ }^{\circ}$ 907, de 1 de marzo de 1977.

Real Decreto n. ${ }^{\circ} 1619$, Por el que se aprueba el Reglamento por el que se regulan las obligaciones de facturación, Boletín Oficial del Estado n. ${ }^{\circ} 289$ España, de 1 de diciembre de 2012. 
Ley n. ${ }^{\circ}$ 67, Ley de Comercio Electrónico, Firmas y Mensajes de Datos, Registro Oficial n. ${ }^{\circ} 557$ Ecuador, de 17 de abril de 2002.

Decreto n. ${ }^{\circ}$ 1.204, Decreto con Fuerza de Ley sobre Mensajes de Datos y Firmas Electrónicas, Gaceta Oficial n. ${ }^{\circ} 37.076$ Venezuela, de 13 de diciembre de 2000.

Ley n. ${ }^{\circ}$ 51, Que define y regula los documentos electrónicos y las firmas electrónicas y la prestación de servicios de almacenamiento tecnológico de documentos y de certificación de firmas electrónicas y adopta otras disposiciones para el desarrollo del comercio electrónico, Gaceta Oficial n. 26.090 Panamá, de 24 de julio de 2008.

Ley n. ${ }^{\circ} 19.983$, Que regula la transferencia y otorga mérito ejecutivo a copia de la factura, Diario Oficial Chile, de 15 de diciembre de 2004.

Decreto Supremo n. ${ }^{\circ}$ 93, Reglamento para la aplicación del artículo noveno de la Ley n. ${ }^{\circ} 19.983$, respecto de la cesión de créditos contenidos en una factura electrónica, Diario Oficial Chile, de 13 de abril de 2005.

Ley n. ${ }^{\circ} 56$, De Medidas de Impulso de la Sociedad de la Información, Boletín Oficial del Estado n. ${ }^{\circ} 312$ España, de 29 de diciembre de 2007.

Ley n. ${ }^{\circ} 25$, De Impulso de la Factura Electrónica y Creación del Registro Contable de Facturas en el Sector Público, Boletín Oficial del Estado n. ${ }^{\circ} 311$ España, de 28 de diciembre de 2013.

Ley n. ${ }^{\circ}$ 59, De Firma Electrónica, Boletín Oficial del Estado n. ${ }^{\circ} 304$ España, de 20 de diciembre de 2003.

Ley n. ${ }^{\circ} 29623$, Ley que promueve el financiamiento a través de la factura comercial, Diario Oficial El Peruano, de 7 de diciembre de 2010.

Ley n. ${ }^{\circ}$ 1231, Por la cual se unifica la factura como título valor como mecanismo de financiación para el micro, pequeño y mediano empresario, y se dictan otras disposiciones, Diario Oficial n. ${ }^{\circ} 47.053$ Colombia, de 17 de julio de 2008.

Ley n. ${ }^{\circ} 1676$, Por la cual se promueve el acceso al crédito y se dictan normas sobre garantías mobiliarias, Diario Oficial n. ${ }^{\circ} 48.888$ Colombia, de 20 de agosto de 2013.

Código de Comercio, Diario Oficial n. ${ }^{\circ} 1140$ El Salvador, de 31 de julio de 1970.

Ley n. ${ }^{\circ}$ 10.406, Instituye el Código Civil, Diario Oficial de Brasil, de 11 de enero de 2002.

Ley n. ${ }^{\circ}$ 58, Ley General Tributaria, Boletín Oficial del Estado n. ${ }^{\circ} 302$ España, de 18 de diciembre de 2002. 
Decreto Ley n. ${ }^{\circ}$ 304, De la contratación económica, Gaceta Oficial Ordinaria n. ${ }^{\circ} 62$ Cuba, de 27 de diciembre de 2012.

Decreto n. ${ }^{\circ}$ 310, De los tipos de contratos, Gaceta Oficial Ordinaria n. ${ }^{\circ} 62$ Cuba, de 27 de diciembre de 2012.

Código de Comercio de Cuba, Real Decreto de la Corona Española, de 28 de enero de 1886.

Dictamen n. ${ }^{\circ}$ 426, Tribunal Supremo Popular de la República de Cuba, Gaceta Oficial Ordinaria n. ${ }^{\circ} 35$, de 7 de septiembre de 2009.

Resolución n. ${ }^{\circ}$ 259, Ministerio de Finanzas y Precios, Gaceta Oficial Extraordinaria n. ${ }^{\circ} 44$ Cuba, de 15 de diciembre de 2008.

Resolución n. ${ }^{\circ}$ 11, Ministerio de Finanzas y Precios, Gaceta Oficial Ordinaria n. ${ }^{\circ} 15$ Cuba, de 12 de febrero de 2007.

Instrucción n. ${ }^{\circ}$ 15, Ministerio de Finanzas y Precios, Gaceta Oficial Ordinaria n. ${ }^{\circ} 67$ Cuba, de 6 de septiembre de 2006.

Instrucción n.$^{\circ}$ 7, Indicaciones a las entidades estatales para la contratación de los productos y servicios de los trabajadores por cuenta propia, Ministerio de Economía y Planificación, Gaceta Oficial Extraordinaria n. ${ }^{\circ} 40$ Cuba, de 21 de noviembre de 2011.

Resolución n. ${ }^{\circ}$ 101, Normas bancarias para los cobros y pagos, Banco Central de Cuba, Gaceta Oficial Extraordinaria n. ${ }^{\circ}$ 40, de 21 de noviembre de 2011.

Decreto-Ley n. ${ }^{\circ}$ 341, De la letra de cambio, el pagaré y el cheque, Gaceta Oficial Ordinaria n. ${ }^{\circ} 7$ Cuba, de 9 de febrero de 2017.

Resolución n. ${ }^{\circ}$ 235, Ministerio de Finanzas y Precios, Gaceta Oficial Ordinaria n. ${ }^{\circ} 44$ Cuba, de 21 de diciembre de 2005.

Resolución n. ${ }^{\circ} 472$, Ministerio de Finanzas y Precios, Gaceta Oficial Ordinaria n. ${ }^{\circ} 3$ Cuba, de 30 de enero de 2013.

Ley n. ${ }^{\circ} 113$, Del Sistema Tributario, Gaceta Oficial Ordinaria n. ${ }^{\circ} 53$ Cuba, de 21 de noviembre de 2012 .

Decreto n. ${ }^{\circ} 308$, Reglamento de las normas generales y de los procedimientos tributarios, Gaceta Oficial Ordinaria n. ${ }^{\circ} 53$ Cuba, de 21 de noviembre de 2012. 


\section{SENTENCIAS}

Sentencia T-727/13 de la Corte Constitucional de la República de Colombia, 17 de octubre de 2013, expediente T-3.870.924. http://www.corteconstitucional.gov. co/relatoria/2013/T-727-13.htm.

Sentencia C-852/09 de la Corte Constitucional de la República de Colombia, 25 de noviembre de 2009, expediente D-7657. http://www.mincit.gov.co/loader.php?l Servicio $=$ Documentos $\&$ IFuncion $=$ verPdf $\&$ id $=21289 \&$ name $=$ SentenciaC $-852-09$. pdf\&prefijo $=$ file.

Sentencia de la Corte Suprema de Chile, 10 de mayo de 2011, causa Rol n. ${ }^{\circ}$ 26-2010.

Sentencia Definitiva Mercantil n. ${ }^{\circ} 454 / 2015$ del Distrito Judicial de Saltillo, México, 30 de noviembre de 2015, expediente 2034/2015. http://pjec.gob.mx/ sentencias/571SP4542015.pdf.

Sentencia n. ${ }^{\circ} 21$ de la Sala de lo Económico del Tribunal Supremo Popular de la República de Cuba, 28 de junio de 2007, en expediente n. ${ }^{\circ} 177$.

Sentencia n. ${ }^{\circ} 222$ de la Sala de lo Económico del Tribunal Supremo Popular de la República de Cuba, 29 de noviembre de 2013, en expediente n. ${ }^{\circ} 234$.

Sentencia n. ${ }^{\circ} 49$ de la Sala de lo Económico del Tribunal Supremo Popular de la República de Cuba, 31 de marzo de 2014, en expediente n. ${ }^{\circ} 54$.

Sentencia n. ${ }^{\circ} 150$ de la Sala de lo Económico del Tribunal Supremo Popular de la República de Cuba, 30 de septiembre de 2015, en expediente n. ${ }^{\circ} 158$.

Sentencia n. ${ }^{\circ} 178$ de la Sala de lo Económico del Tribunal Supremo Popular de la República de Cuba, 30 de septiembre de 2016, en expediente n. ${ }^{\circ} 192$.

Sentencia n. ${ }^{\circ} 3140$ de la Sala de lo Penal del Tribunal Supremo Popular de la República de Cuba, 7 de noviembre de 2014, en causa n. ${ }^{\circ} 114$. 